\title{
Rapid formation of large aggregates during the spring bloom of Kerguelen Island: observations and model comparisons
}

\author{
M.-P. Jouandet ${ }^{1}$, G. A. Jackson ${ }^{2}$, F. Carlotti ${ }^{1}$, M. Picheral ${ }^{3}$, L. Stemmann ${ }^{4}$, and S. Blain ${ }^{5,6}$ \\ ${ }^{1}$ Mediterranean Institute of Oceanography (MIO), Unité mixte: Aix Marseille Université - CNRS - IRD, 13288 Marseille \\ CEDEX 09, France \\ ${ }^{2}$ Department of Oceanography, Texas A\&M University, College Station, TX 77845-3146, USA \\ ${ }^{3}$ CNRS, UMR7093, LOV, Observatoire océanologique, 06230, Villefranche/mer, France \\ ${ }^{4}$ Sorbonne Universités, UPMC Univ Paris 06, UMR7093, LOV, Observatoire océanologique, 06230, Villefranche/mer, France \\ ${ }^{5}$ Sorbonne Universités, UPMC Univ Paris 06, UMR7621, Laboratoire d'Océanographie Microbienne, Observatoire \\ Océanologique, 66650 Banyuls/mer, France \\ ${ }^{6}$ CNRS, UMR7621, Laboratoire d'Océanographie Microbienne, Observatoire Océanologique, 66650 Banyuls/mer, France
}

Correspondence to: M.-P. Jouandet (marie-paule.jouandet@univ-amu.fr)

Received: 17 March 2014 - Published in Biogeosciences Discuss.: 28 March 2014

Revised: 24 June 2014 - Accepted: 28 June 2014 - Published: 20 August 2014

\begin{abstract}
While production of aggregates and their subsequent sinking is known to be one pathway for the downward movement of organic matter from the euphotic zone, the rapid transition from non-aggregated to aggregated particles has not been reported previously. We made one vertical profile of particle size distributions (PSD; sizes ranging from 0.052 to several millimeters in equivalent spherical diameter) at pre-bloom stage and seven vertical profiles 3 weeks later over a $48 \mathrm{~h}$ period at early bloom stage using the Underwater Vision Profiler during the Kerguelen Ocean and Plateau Compared Study cruise 2 (KEOPS2, OctoberNovember 2011). In these naturally iron-fertilized waters southeast of Kerguelen Island (Southern Ocean), the total particle numerical abundance increased by more than fourfold within this time period. A massive total volume increase associated with particle size distribution changes was observed over the $48 \mathrm{~h}$ survey, showing the rapid formation of large particles and their accumulation at the base of the mixed layer. The results of a one-dimensional particle dynamics model support coagulation as the mechanism responsible for the rapid aggregate formation and the development of the $V_{\mathrm{T}}$ subsurface maxima. The comparison of $V_{\mathrm{T}}$ profiles between early bloom stage and pre-bloom stage indicates an increase of particulate export below $200 \mathrm{~m}$ when bloom has developed. These results highlight the role of coagulation in forming large particles and triggering carbon export at the
\end{abstract}

early stage of a naturally iron-fertilized bloom, while zooplankton grazing may dominate later in the season. The rapid changes observed illustrate the critical need to measure carbon export flux with high sampling temporal resolution. Our results are the first published in situ observations of the rapid accumulation of marine aggregates and their export and the general agreement of this rapid event with a model of phytoplankton growth and coagulation.

\section{Introduction}

Biological particle production and sedimentation out of the euphotic layer to underlying waters is the major mechanisms for atmospheric $\mathrm{CO}_{2}$ removal and the redistribution of carbon and associated nutrients in the ocean. The fate of this exported particulate carbon is a function of the plankton community producing it in the upper layer and particle transformation by microbes and zooplankton during their descent to the deep sea. Physical aggregation of particles is one key process in this transformation and transport and can explain the rapid formation and export of large particles during bloom conditions.

The Southern Ocean is the largest high-nutrient, lowchlorophyll (HNLC) region of the global ocean. However, several areas in this biological desert display strong seasonal 
phytoplankton blooms. Since the HNLC regions result from low supplies of the crucial nutrient iron, the hypothesis is that these blooms are supported by natural sources of iron, most likely supplied from local islands and shallow sediment (Moore and Abbott, 2002; Tyrrell et al., 2005; Blain et al., 2007; Pollard et al., 2007).

The impact of iron on the biological carbon pump has been investigated in these natural bloom regions (Blain et al., 2007; Pollard et al., 2007) and in patches formed by adding iron to localized HNLC regions (Boyd et al., 2000, 2004; Gervais et al., 2002; Buesseler et al., 2004, 2005; de Baar et al., 2005; Hoffmann et al., 2006; Smetacek et al., 2012; Martin et al., 2013). The observations made during the naturaliron fertilization programs KEOPS1 (Kerguelen Ocean and Plateau Compared Study) and CROZEX (CROZet natural iron bloom and EXport experiment) documented a twofold greater carbon export flux downward from the mixed layer (ML) in the naturally iron-fertilized bloom relative to that in unfertilized surrounding waters (Jouandet et al., 2008, 2011; Savoye et al., 2008; Pollard et al., 2009). An increase in Particulate Organic Carbon (POC) flux after artificial fertilization experiments was detected only during SOFeX (Southern Ocean Fe Experiment; Buesseler et al., 2005) and EIFEX (European Iron Fertilization Experiment; Smetacek et al., 2012).

Optical examination of particles trapped in polyacrylamide gels during KEOPS 1 found that export at 100-430 m was dominated by fecal pellets and fecal aggregates (Ebersbach and Trull, 2008), which can be considered as a form of indirect export. (Note that we consider direct export to be the flux of phytoplankton cells, either alone or in aggregates.) By contrast, the CROZEX experiment observed direct export of surface production by a diverse range of diatoms (Salter et al., 2007), consistent with phytoplankton aggregation enhancing particulate flux. The lack of phytoplankton aggregation due to insufficient biomass has been invoked as the reason for which carbon export flux in SOIREE (Southern Ocean Iron Release Experiment) was not enhanced (Waite and Nodder, 2001; Jackson et al., 2005). The different results for these systems reflect differences in physical forcing factors, experimental duration, and seasonal evolution of the biological community.

Because of the complexity of the export system, there are still extensive unknowns about the effect of iron fertilization on carbon export from the surface to the bottom layer. The aim of our study is to investigate processes responsible for the formation of large particles $(>52 \mu \mathrm{m})$ on a short timescale during bloom development in the surface ML.

We combine multiple vertical profiles of large-particle size spectra collected over a relatively short period during KEOPS2 with a one-dimensional particle dynamics model that incorporates phytoplankton growth as a function of light and nitrate concentration and coagulation as function of aggregate size. We measured particle distributions using the Underwater Vision Profiler (UVP) deployed at a bloom sta- tion above the Kerguelen plateau under pre-bloom conditions and at an early bloom stage during a period of rapid change. The coagulation model used here is an extension of a zerodimensional model that simulates abundances of phytoplankton cells in the surface mixed layer as well as the size distributions of settling particles (e.g., Jackson et al., 2005; Jackson and Kiørboe, 2008). Here it has been extended into a one-dimensional model to describe the vertical distribution of phytoplankton in the mixed layer and the formation, distribution, and flux of aggregates. The comparison between observed and modeled particle size distribution provides a unique opportunity to test the usefulness of the coagulation theory to explain rapid formation of large aggregates during the early stage of a phytoplankton bloom.

\section{Material and methods}

\subsection{Field measurements}

Station A3 $\left(50^{\circ} 380 \mathrm{~S}, 72^{\circ} 050 \mathrm{E}\right)$, located above the Kerguelen plateau, is characterized by a weak current (speed $<3 \mathrm{~cm} \mathrm{~s}^{-1}$; Park et al., 2008b), which results in a water mass residence time of several months. This long residence time allows the bloom to develop and persist over an entire season in response to natural-iron fertilization (Blain et al., 2007). During KEOPS2, Station A3 was sampled first during pre-bloom conditions on 21 October 2011 (A3-1) and was revisited during the early bloom from 15 to 17 November (A3-2), 2 weeks after the bloom had started. High sampling frequency started during the second visit at midnight on 15 November (Table 1).

The Underwater Vision Profiler 5 (UVP 5 Sn002) used in the present study was a component of the rosette profiler system. The UVP5 detects and measures particles larger than $52 \mu \mathrm{m}$ on images acquired at high frequency (Picheral et al., 2010). Images were taken and data recorded at a frequency of $6 \mathrm{~Hz}$, corresponding to a distance of $20 \mathrm{~cm}$ between images at the $1 \mathrm{~m} \mathrm{~s}^{-1}$ lowering speed of the conductivity-temperaturedepth (CTD) system. The observed volume per image is $0.48 \mathrm{dm}^{3}$; the total volume sampled for the $500 \mathrm{~m}$ depth profiles at Station A3 was $1.2 \mathrm{~m}^{3}$. The instrument takes a digital picture of a calibrated volume lit from the side. The image is scanned for particles and particle dimensions are measured. The pixel area $\left(S_{\mathrm{p}}\right)$ for each object is converted to cross-sectional area $\left(S_{m}\right)$ using the calibration equation $S_{m}=$ $0.00018 S_{\mathrm{p}}^{1.452}$. An equivalent spherical diameter $d$ is calculated for that cross-sectional area. Hydrographic and biogeochemical properties, including density, fluorescence, and turbidity (as determined by a transmissometer using a wavelength of $660 \mathrm{~nm}$ and a $25 \mathrm{~cm}$ path length), were measured simultaneously with a conductivity-temperature-depth system (Seabird SBE-911 + CTD) linked to a Seapoint Chelsea Aquatracka III (6000 m) chlorophyll fluorometer and a WET Labs C-Star (6000 m) Transmissometer. 
Table 1. Date and time of the casts performed at Station A3.

\begin{tabular}{lcrc}
\hline Station & $\begin{array}{c}\text { Date } \\
\text { (dd-mm-yyyy) }\end{array}$ & $\begin{array}{r}\text { Time (LT) } \\
(\mathrm{hh}: \mathrm{mm})\end{array}$ & $\begin{array}{c}\text { Mixed layer } \\
\text { depth }(\mathrm{m})\end{array}$ \\
\hline A3-1 & $21-10-2011$ & $02: 20$ & 165 \\
A3-2/1 & $15-11-2011$ & $23: 20$ & 143 \\
A3-2/2 & $16-11-2011$ & $07: 50$ & 171 \\
A3-2/3 & $16-11-2011$ & $11: 30$ & 138 \\
A3-2/4 & $16-11-2011$ & $19: 15$ & 147 \\
A3-2/5 & $17-11-2011$ & $01: 10$ & 123 \\
A3-2/6 & $17-11-2011$ & $05: 30$ & 163 \\
A3-2/7 & $17-11-2011$ & $14: 30$ & 124 \\
\hline
\end{tabular}

We also present selected results of chlorophyll $a(\mathrm{Chl} a)$ and nitrate concentrations, as well as relative biomass of different phytoplankton size classes. Chl $a$ and pigment concentrations were measured using high-performance liquid chromatography (HPLC) following the method described in Lasbleiz et al. (2014); the fraction of a phytoplankton group relative to the total biomass was calculated using the model of Uitz et al. (2006). Nitrate was analyzed with a Technicon AutoAnalyzer as described in Tréguer and LeCorre (1975).

\subsection{Data processing}

The particles in each $5 \mathrm{~m}$ depth interval, with depth determined from the associated CTD measurements, were sorted into 27 diameter intervals (from 0.052 to $27 \mathrm{~mm}$, spaced geometrically), and concentrations were calculated for each diameter and depth interval. We further analyzed size spectra having a minimum of five particles per size bin and depth interval; this criterion eliminated bins with $d>1.6 \mathrm{~mm}$. The depth distributions of particles are summarized in terms of their total number $N_{\mathrm{T}}\left(\# \mathrm{~L}^{-1}\right)$ and volume $V_{\mathrm{T}}\left(\mathrm{mm}^{3} \mathrm{~L}^{-1}=\mathrm{ppm}\right)$ concentrations.

Particle number distributions $(n)$ were calculated by dividing the number of particles $(\Delta N)$ within a given bin by the width of the ESD (Equivalent Spherical Diameter) bin $(\Delta d)$ and the sample volume. The resulting units are $\# \mathrm{~cm}^{-4}$. The distributions are usually plotted in a log-log plot because of the large ranges in $n$ and $d$. To compensate for these ranges, the results are often displayed as $n V d$ spectra, where $n$ is multiplied by the median diameter $(d)$ and the spherical volume $V=\pi / 6 d^{3}$ for the particle size range. This form of the particle size distribution has the advantage that the area under the curve is proportional to the total particle volume concentration when $n V d$ is plotted against $\log (d)$. The carbon export flux $F_{\text {POC }}\left(\mathrm{mg} \mathrm{C} \mathrm{m}^{-2} \mathrm{~d}^{-1}\right)$ can be estimated from the size spectra using the following empirical relationship:

$F_{\mathrm{POC}}=A d^{b}$,

where $d$ is the diameter in millimeters, $A=12.5$, and $b=$ 3.81 (Guidi et al., 2008). Guidi et al. (2008) developed the relationship by comparing particle size spectra to sediment trap collection rates at locations around the world. The value of $b$ is less than the value of 5 expected for spherical particles of constant density (for which mass increases as $d^{3}$ and sinking speed as $d^{2}$ ). It is consistent with marine aggregates having increasing porosity with increasing size (e.g., Alldredge and Gotschalk, 1988).

\subsection{Model equations and parameterization}

The biological model describes the growth rate of phytoplankton in the water column as a function of light and nutrient (nitrate) concentration. The model uses a maximum phytoplankton specific growth rate $G_{\max }=0.45 \mathrm{~d}^{-1}$ (Timmermans et al., 2004; Assmy et al., 2007). Phytoplankton cells are transformed into aggregates by differential settling and shear using the standard coagulation model of Jackson (1995). Aggregates are also fragmented into two similar parts using size-dependent disaggregation rates (Jackson, 1995). The primary phytoplankton cells are chosen to match the size of Fragilariopsis kerguelensis which was the dominant species under pre-bloom conditions (L. Armand, personal communication, 2014). A single phytoplankton cell has $d_{1}=$ $20 \mu \mathrm{m}$, a density of $1.0637 \mathrm{~g} \mathrm{~cm}^{-1}$, and a resulting settling speed of $v_{1}=1.05 \mathrm{~m} \mathrm{~d}^{-1}$. The probability that two particles colliding stick together, $\alpha$, is assumed to be 1 . The average turbulent shear rate is $\gamma=1 \mathrm{~s}^{-1}$ (Jackson et al., 2005). The initial abundance of phytoplankton is 10 cells $\mathrm{cm}^{-3}$. These and other parameter values are shown in Table 2. The onedimensional model simulates the distribution of particles of different sizes, including solitary phytoplankton cells, and nitrate concentrations at $2 \mathrm{~m}$ depth intervals within the $0-150 \mathrm{~m}$ layer. This depth range corresponds to the average surface ML thickness during the survey (Table 1). Neither zooplankton grazing nor particle transformation by bacterial processes is included in these simulations. The model is described in greater detail in Supplement S1.

While the concept of spherical diameter is simple for a solid sphere, it is not for irregular marine aggregates, with different shapes, assembled from multiple sources, having water in the interstices between their components and yielding different sizes for different measurement techniques (e.g., Jackson, 1995). The simplest diameter is the conserved diameter $d_{\mathrm{c}}$, i.e. the diameter if all the solid matter were to be compressed into a solid sphere. It has the advantage that when two particles collide and form a new particle, the conserved volume of the new particle is the sum of the conserved volumes of the two colliding particles. The particle diameter $d$, determined by the UVP, is larger than $d_{\mathrm{c}}$ because aggregate size is determined from the outer shape of the aggregate and thus contains pore water between source particles. The relationship between the two measures of particle diameter is described using the fractal dimension (see Supplement S1). The model calculations use $d_{\mathrm{c}}$. However, all model results shown here use the apparent diameter $d_{\mathrm{a}}$, which is used to approximate the diameter reported by the UVP. The value of 
Table 2. Symbols and parameter values used for the model. Conversion constants include the following: carbon to chlorophyll $50 \mathrm{~g} \mathrm{C}: \mathrm{g} \mathrm{Chl} a$; carbon to nitrogen $-106 \mathrm{~mol} \mathrm{C}: 16 \mathrm{~mol} \mathrm{~N}$.

\begin{tabular}{|c|c|c|c|c|}
\hline Symbol & Quantity & Value & Units & Reference \\
\hline$d_{\mathrm{c}}$ & Conserved diameter & & $\mathrm{cm}$ & \\
\hline$d_{\mathrm{a}}$ & Apparent diameter & & $\mathrm{cm}$ & \\
\hline$d_{1}$ & Median algal diameter & 20 & $\mu \mathrm{m}$ & \\
\hline$D_{\text {fr }}$ & Fractal dimension & 2 & - & \\
\hline G & Specific growth rate & & $d^{-1}$ & \\
\hline$G_{\max }$ & Maximum specific growth rate & 0.45 & $d^{-1}$ & Timmermans et al. (2004) \\
\hline$I$ & Irradiance & & $\operatorname{ly~d} \mathrm{d}^{-1}$ & \\
\hline$I_{o}$ & Surface irradiance & & ly d $\mathrm{d}^{-1}$ & Evans and Parslow (1985) \\
\hline$k$ & Total light attenuation $-k_{\mathrm{w}}+k_{\mathrm{r}} P$ & & $\mathrm{~m}^{-1}$ & \\
\hline$k_{\mathrm{r}}$ & Coefficient for light attenuation by plants & 0.03 & $\mathrm{~m}^{2}(\mathrm{mmol} \mathrm{N})^{-1}$ & Fasham et al. (1990) \\
\hline$k_{\mathrm{w}}$ & Light attenuation of water & 0.04 & $\mathrm{~m}^{-1}$ & Fasham et al. (1990) \\
\hline$K_{d}$ & Half saturation constant & 1 & $\mathrm{mmol} \mathrm{Nm^{-3 }}$ & Fasham et al. (2006) \\
\hline$K_{z}$ & Eddy diffusivity & 100 & $\mathrm{~m}^{2} \mathrm{~d}^{-1}$ & Park et al. (2008a) \\
\hline$m$ & Particle mass & & $\mathrm{g}$ & \\
\hline$n(d)$ & Number spectrum for diameter $d$ & & $\mathrm{~cm}^{-4}$ & \\
\hline$n(m)$ & Number spectrum for mass $m$ & & $\mathrm{~cm}^{-3} \mathrm{~g}^{-1}$ & \\
\hline$N$ & Nitrate concentration & & $\mathrm{mmol} \mathrm{Nm}^{-3}$ & \\
\hline$Q_{i}$ & Particle mass in $i$ th section & & $\mathrm{g}$ & \\
\hline$r$ & Phytoplankton mortality rate & 0.04 & $d^{-1}$ & Assmy et al. (2007) \\
\hline$r_{\mathrm{p}}$ & Relative light limitation & & - & \\
\hline$r_{\mathrm{n}}$ & Relative nitrate limitation & & - & \\
\hline$v_{i}$ & Settling velocity for particle in $i$ th section & & $\mathrm{md}^{-1}$ & \\
\hline$V$ & Particle volume & & & \\
\hline$\alpha_{I}$ & Slope of photosyn. curve & & $0.04 \mathrm{ly}^{-1}$ & Evans and Parslow (1985) \\
\hline$\alpha$ & Stickiness & 1 & - & Jackson et al. (2005) \\
\hline$\beta$ & Coagulation kernels & & & \\
\hline $\begin{array}{c}{ }^{1} \beta_{i, j, l},{ }^{2} \beta_{i, l}, \\
{ }^{3} \beta_{l,}{ }^{4} \beta_{i},\end{array}$ & Sectional coefficients & & & \\
\hline$\phi$ & Phytoplankton concentration & & $\mathrm{mmol} \mathrm{N} \mathrm{m}^{-3}$ & \\
\hline$\lambda_{i}$ & Disaggregation coef. for $i$ th section & & $d^{-1}$ & Jackson (1995) \\
\hline$\gamma$ & Fluid shear & 1 & $\mathrm{~s}^{-1}$ & Jackson et al. (2005) \\
\hline$\mu$ & Average algal growth rate & & $\mathrm{d}^{-1}$ & \\
\hline
\end{tabular}

$d_{\mathrm{a}}$ is calculated from $d_{\mathrm{c}}$ using the fractal relationship and a fractal dimension of 2 (Supplement S1). Note that reported values of the fractal dimension vary widely, from 1.3 to 2.3 (Burd and Jackson, 2009). The value of 2 used here is in this range and yields peaks in the $n V d$ distributions similar to those determined from UVP measurements, unlike values of 2.1 and 1.9 (not shown).

\section{Results}

\subsection{Observations}

\subsubsection{Biogeochemical and physical context}

The water column was characterized by a deep mixed layer $(\sim 150 \mathrm{~m})$ during the pre-bloom and early bloom surveys, with a range of 120 to $171 \mathrm{~m}$ (Figs. 1 and 2). Isopycnal dis- placements of up to $50 \mathrm{~m}$ can be seen in the density profiles. Such vertical movements are known to result from semidiurnal internal tides in this region (Park et al., 2008a). The fluorescence and Chl $a$ concentrations show a fourfold increase from A3-1 (21 October) to A3-2 (15-17 November), with Chl $a$ concentrations at the surface increasing from 0.5 to $\sim 2 \mu \mathrm{g} \mathrm{L}{ }^{-1}$ (Figs. 1 and 2). The Chl $a$ profile determined using bottle samples for Station A3-2 was characterized by a subsurface maximum at $170 \mathrm{~m}$, at the bottom of the mixed layer (Fig. 3). The chlorophyll profiles determined using the in situ fluorometer were either relatively constant or had maxima at $50 \mathrm{~m}$ or shallower (Figs. 1 and 2). Variations in the maximum depth of fluorescence from the in situ profiles were associated with temporary deepening of the mixed layer at $07: 50$ and $19: 15 \mathrm{LT}$ on 16 November and at $05: 30 \mathrm{LT}$ on 17 November. In the surface mixed layer, the beam attenuation coefficient (turbidity) had a similar distribution as 


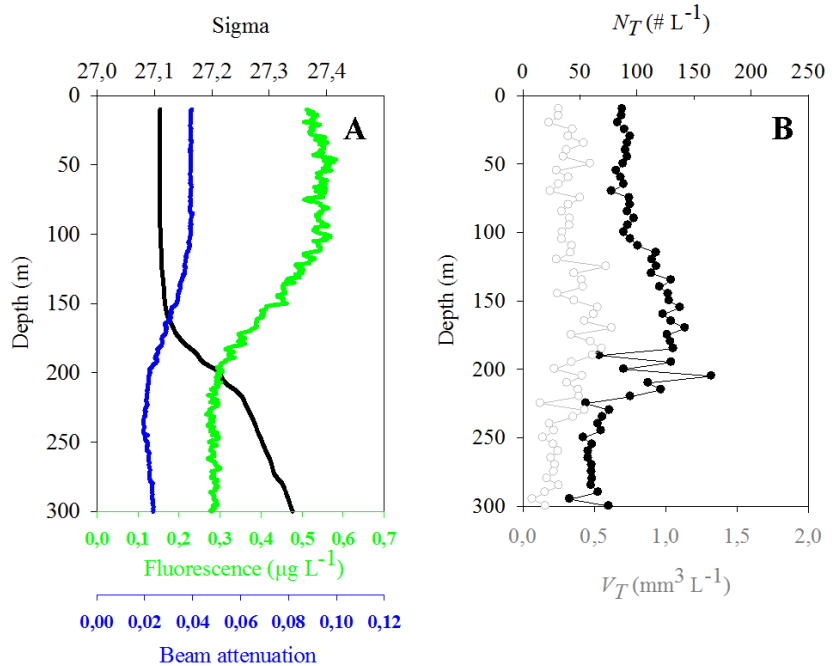

Figure 1. Vertical distribution of sigma (black line), fluorescence (green line), and turbidity (blue line) (A) and vertical profiles of total abundance $\left(N_{\mathrm{T}}\right)$ and total volume $\left(V_{\mathrm{T}}\right)$ at the first cast of $\mathrm{A} 3$, during winter (A3-1, 21 of October) (B).

fluorescence (Figs. 1 and 2). The two were, in fact, highly correlated in the surface mixed layer $(r=0.95)$, which was not always the case in deeper layers. Nitrate concentrations at A3-1 were 28 to $30 \mu \mathrm{M}$ in the mixed layer and then decreased by $4 \mu \mathrm{M}$ at A3-2 (Fig. 3a). Pigment analysis (Fig. 3) and cell counts of phytoplankton captured in nets (L. Armand, personal communication, 2014) showed that the phytoplankton community was dominated by diatoms - Fragilariopsis at A3-1 and an assemblage of Fragilariopsis, Chaetoceros , and Pseudo-nitzschia at A3-2. The zooplankton community was dominated by copepods with a mixture of adult $(50.5 \%)$ and copepodites stage $(49.5 \%)$ at A3-2 (Carlotti et al., 2014). Zooplankton biomass increased from $1.4 \mathrm{~g} \mathrm{C} \mathrm{m}^{-2}$ at $\mathrm{A} 3-1$ to $4.1 \mathrm{~g} \mathrm{C} \mathrm{m}^{-2}$ at A3-2 over the 0-250 m layer, and was thus more than twofold lower than the mean biomass of $10.6 \mathrm{~g} \mathrm{C} \mathrm{m}^{-2}$ measured at $\mathrm{A} 3$ in summer during KEOPS1 (Carlotti et al., 2008).

\subsubsection{Evolution of the total abundance and volume distributions in the mixed layer}

In the pre-bloom profile, total particle abundance $\left(N_{\mathrm{T}}\right)$ and volume $\left(V_{\mathrm{T}}\right)$ distributions at Station $\mathrm{A} 3$ were characterized by a two-layer structure (Fig. 1b). The shallower layer had relatively uniform $N_{\mathrm{T}}\left(V_{\mathrm{T}}\right)$ values of $90 \pm 5$ particles $\mathrm{L}^{-1}$ $\left(0.3 \pm 0.1 \mathrm{~mm}^{3} \mathrm{~L}^{-1}\right)$ between 0 and $100 \mathrm{~m}$; the second layer, from $100 \mathrm{~m}$ to the base of the ML $(166 \mathrm{~m})$, had subsurface $N_{\mathrm{T}}$ and $V_{\mathrm{T}}$ maxima of 142 particles $\mathrm{L}^{-1}$ and $0.45 \mathrm{~mm}^{3} \mathrm{~L}^{-1}$. There was a twofold increase in $N_{\mathrm{T}}$ at the first cast of the early bloom (A3-2/1), with values reaching $200 \pm 7 \mathrm{\#}^{-1}$ in the first $100 \mathrm{~m}$ and a subsurface maximum of $300 \# \mathrm{~L}^{-1}$ (Fig. 4). $V_{\mathrm{T}}$ also increased by one order of magnitude reach-
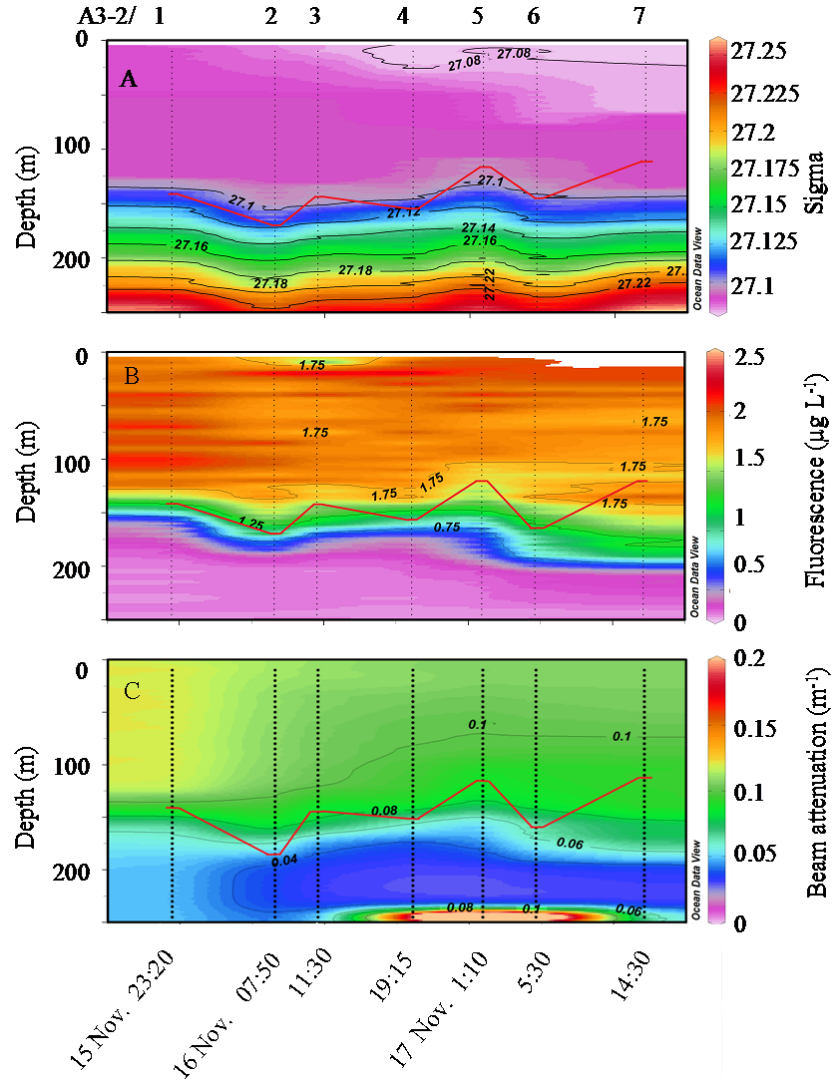

Figure 2. Temporal evolution of density (A), fluorescence (B), and turbidity $(\mathbf{C})$ during the spring survey. The red line shows the mixed layer depth
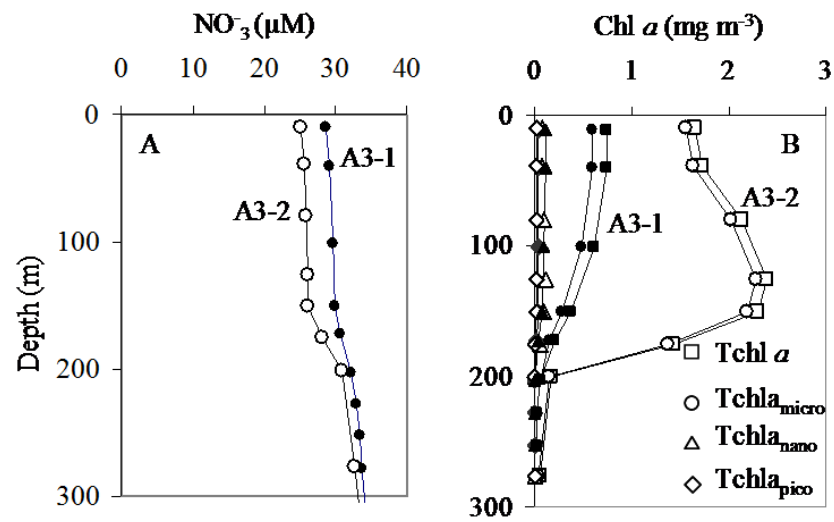

Figure 3. Vertical distribution of the concentration of $\mathrm{NO}_{3}$ (A); total Chl $a\left(T_{\operatorname{chl} a}\right)$, and $T_{\operatorname{chl} a}$ associated with micro- $\left(T_{\operatorname{chl} a_{\text {micro }}}\right)$, nano$\left(T_{\text {chl } a_{\text {nano }}}\right)$, and picophytoplankton $\left(T_{\text {chl } a_{\text {pico }}}\right)(\mathbf{B})$. The filled symbols indicate pre-bloom stage; the hollow symbols indicate early bloom stage.

ing a value of $3 \mathrm{~mm}^{3} \mathrm{~L}^{-1}$ at the depth of the subsurface maxima (Fig. 4). In subsequent casts, there was a $40 \mathrm{~m}$ thick surface layer with constant $N_{\mathrm{T}}$ and $V_{\mathrm{T}}$ and a subsurface maximum present at variable depths. Particularly striking was 

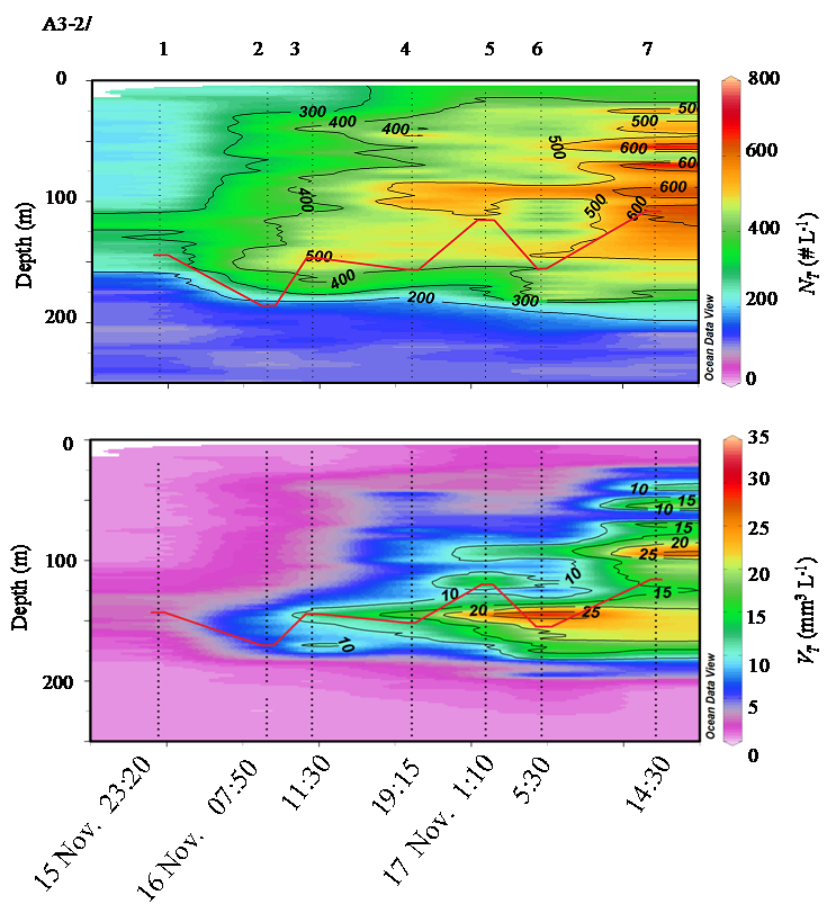

Figure 4. Vertical distribution of $N_{\mathrm{T}}$ and $V_{\mathrm{T}}$ for the different casts during early bloom stage.

the rapid and continuous increase of both $N_{\mathrm{T}}$ and $V_{\mathrm{T}}$ from A3-2/1 to A3-2/5 over a roughly $24 \mathrm{~h}$ time period. This was more than a redistribution of aggregates, as $N_{\mathrm{T}}$ and $V_{\mathrm{T}}$ integrated over the ML increased from 282 to $743 \#^{-2}$ and from $101 \times 10^{3}$ to $1500 \times 10^{3} \mathrm{~mm}^{3} \mathrm{~m}^{-2}$. There was a further increase by the end of the survey in the maximum $V_{\mathrm{T}}$ to $25 \mathrm{~mm}^{3} \mathrm{~L}^{-1}$, almost two orders of magnitude greater than for the pre-bloom situation.

\subsubsection{Evolution of size distributions with depth and time during the early bloom phase}

The particle size distributions (PSD) calculated from the UVP observations provide additional insight into the change in particle abundance during the $2 \mathrm{~d}$ spring observation period. In order to display the vertical structure of PSD, we compare the average over the nominal euphotic zone ( 0 to $40 \mathrm{~m}$ ) to the average over the $40 \mathrm{~m}$ layer centered on the subsurface particle maximum. Particles larger than $129 \mu \mathrm{m}$ were more abundant in the subsurface layer (Fig. 5a). Consistent with the analysis in the previous section, the smallest difference between the two layers occurred during the pre-bloom sampling (A3-1). The maximum increases were in the 0.128$0.162 \mathrm{~mm}$ and $0.204-0.257 \mathrm{~mm}$ size classes, with abundance increases of $66 \mathrm{~L}^{-1}$ and $62 \mathrm{~L}^{-1}$ for $\mathrm{A} 3-2 / 3$. The increase was also substantial in the $0.4-0.5 \mathrm{~mm}$ size range. The cumulative volume distribution in the $0-40 \mathrm{~m}$ euphotic zone shows that increased particle volumes resulted from formation of larger particles (Fig. 5b).
Within the vertical particle maxima, half of $V_{\mathrm{T}}$ was in particles with $d>0.5 \mathrm{~mm}$ at the start of the survey, while these larger particles provided more than $80 \%$ at the end. The largest change in size spectra was in the approximately $17.5 \mathrm{~h}$ period between the morning (A3-2/2) and the middle of the night (A3-2/5) of 16 November.

The $n V d$ size distribution for profile A3-2/5 is shown in detail in Fig. 6. The area under the curve at a constant depth is proportional to the particle volume $V_{\mathrm{T}}$ at that depth. Between the surface and $60 \mathrm{~m}$ most particle volume is made up of the smallest size class with particles $d$ ranging between 200 and $500 \mu \mathrm{m}$. Massive changes occurred with depth with an increase of the volume and $d$. The volumes from $60 \mathrm{~m}$ to $150 \mathrm{~m}$ are supported by larger particles ranging between $0.65 \mathrm{~mm}$ and $1.1 \mathrm{~mm}$, with a peak of $30 \mathrm{ppm}$ for a $d$ of $1 \mathrm{~mm}$.

\subsubsection{Particle distributions below the ML}

In the first $50 \mathrm{~m}$ below the ML, $V_{\mathrm{T}}$ values mirrored those in the overlying waters, increasing to $20 \mathrm{ppm}$ by the end of the survey period (A3-2/7) (Fig. 7). $V_{\mathrm{T}}$ decreased from the base of the ML to $200 \mathrm{~m}$ by about a factor of 20 for A3-2/6 and A3-2/7. Below $200 \mathrm{~m}$, the depth limit for winter mixing, there was no change in $V_{\mathrm{T}}$ during the $2 \mathrm{~d}$ survey. The average $V_{\mathrm{T}}$ was $0.40 \pm 0.10$ and $0.38 \pm 0.10 \mathrm{~mm}^{3} \mathrm{~L}^{-1}$ at 250 and $350 \mathrm{~m}$. There was an increase in $V_{\mathrm{T}}$ at about $475 \mathrm{~m}$ caused by resuspension from the bottom, as documented during KEOPS1 (Chever et al., 2010; Jouandet et al., 2011). The particle number distribution $(n)$ decreased from the base of the mixed layer to $350 \mathrm{~m}$ in all size classes, particularly for particles larger than $500 \mu \mathrm{m}$, which were no longer detectable (Fig. 7b).

\subsubsection{Relationship between particle volume and fluorescence}

As mentioned, there was no simple correlation between $V_{\mathrm{T}}$ and fluorescence. However, separating the observations by depth layers (the mixed layer, the base of the ML to $200 \mathrm{~m}$ and deeper than $200 \mathrm{~m}$ ) reveals a pattern (Fig. 8). In the shallowest layer, there was an increase from the pre-bloom values of low fluorescence and particle volume for A31 (21 October) to high fluorescence and low particle volume for A3-2/1 (15 November, 23:20 LT). This is consistent with an increase in phytoplankton biomass without aggregate production. For A3-2/2, there are hints of an increase in $V_{\mathrm{T}}$, which became pronounced in subsequent casts. The increased particle concentrations were accompanied by a slight decrease in fluorescence. For the seven casts performed during the early bloom stage, the correlations between fluorescence and $V_{\mathrm{T}}$ were negative $(-0.53)$, with a slope of

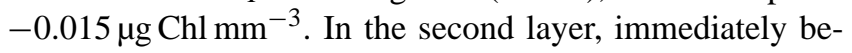
low the surface mixed layer, fluorescence and $V_{\mathrm{T}}$ increased together, with a positive correlation coefficient $(0.68)$ and a slope of $0.036 \mu \mathrm{g} \mathrm{Chl} \mathrm{mm}{ }^{-3}$ (Fig. 8). This is consistent with 

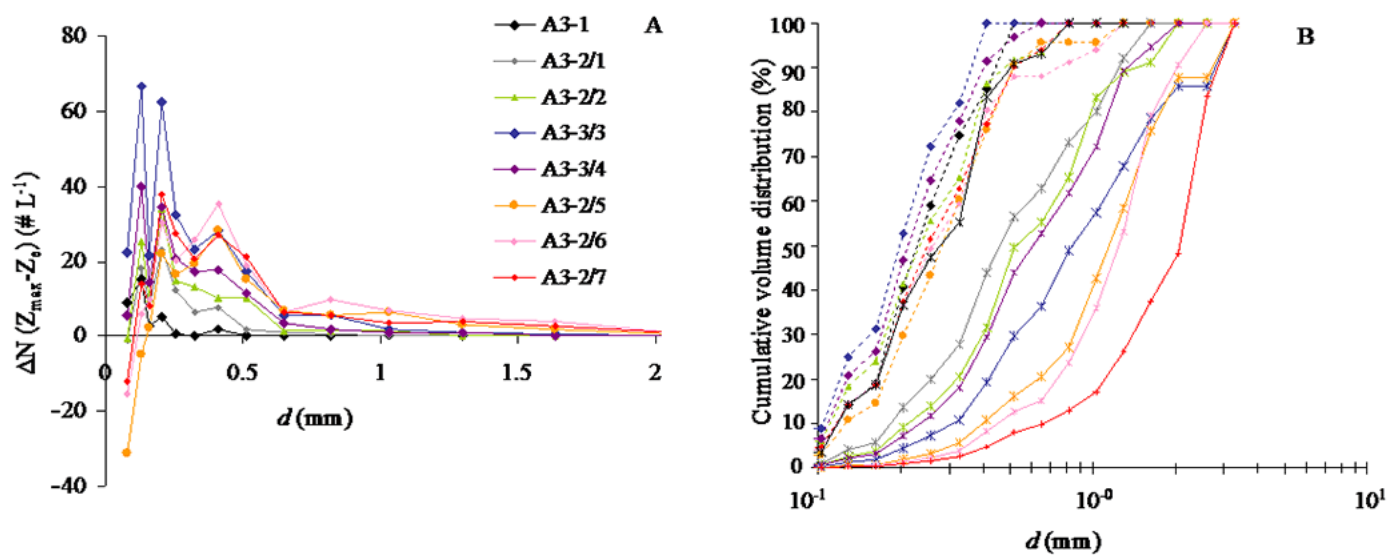

Figure 5. Difference of the size spectra abundance between the depth of the volume maxima $\left(Z_{\max }\right)$ and the euphotic layer $\left(Z_{\mathrm{e}}\right)(\mathbf{A})$ and cumulative volume distribution $(\mathbf{B})$ in the euphotic layer (dashed line) and at the depth of the $V_{\mathrm{T}}$ subsurface maxima (solid line).

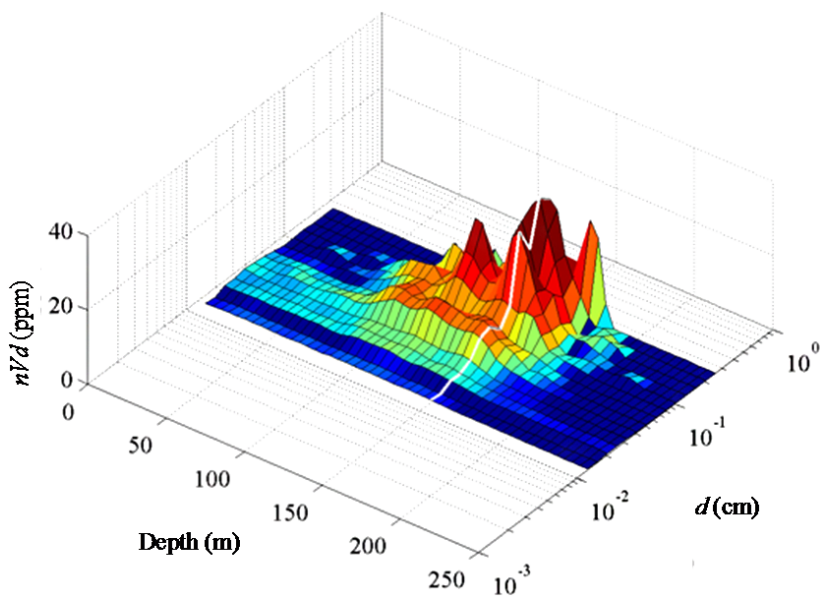

Figure 6. Volume distribution size spectra along vertical axis on the 17 of November at $01: 10 \mathrm{LT}(\mathrm{A} 3-2 / 5)$. The white line indicates values at $150 \mathrm{~m}$, the bottom of the model regime.

no phytoplankton growth in this depth layer, but with phytoplankton and aggregates arriving together from above, presumably in aggregates. There was no correlation between fluorescence and $V_{\mathrm{T}}$ below $200 \mathrm{~m}$ during this period.

\subsubsection{POC flux}

The flux at $200 \mathrm{~m}$ computed from the UVP particle size distributions increased from $1.8 \mathrm{mg} \mathrm{m}^{-2} \mathrm{~d}^{-1}$ during pre-bloom conditions to $23 \mathrm{mg} \mathrm{C} \mathrm{m}^{-2} \mathrm{~d}^{-1}$ during the early bloom (last cast of the survey). This increase over time as estimated from UVP measurements was also evident at $400 \mathrm{~m}$ but with a smaller change, with $F_{\mathrm{POC}}$ increasing from 1.04 to $3.5 \mathrm{mg} \mathrm{C} \mathrm{m}^{-2} \mathrm{~d}^{-1}$ at $400 \mathrm{~m}$ (Table 3).
Our POC flux estimates at $200 \mathrm{~m}$ for the spring bloom are in the range of the POC flux estimated from the sediment trap PPS3/3 $\left(27 \pm 8 \mathrm{mg} \mathrm{C} \mathrm{m}^{-2} \mathrm{~d}^{-1}\right)$ and below the estimates made from the gel trap $\left(F_{\mathrm{POC}}=66 \mathrm{mg} \mathrm{Cm}^{-2} \mathrm{~d}^{-1}\right)$ and from the thorium deficit $\left(F_{\mathrm{POC}-\mathrm{Th}}=32 \mathrm{mg} \mathrm{C} \mathrm{m}^{-2} \mathrm{~d}^{-1}\right)$ (Laurenceau et al., 2014; Planchon et al., 2014). $F_{\mathrm{POC}-\mathrm{Th}}$ at $100 \mathrm{~m}$ increased from pre-bloom to early bloom but stayed unchanged at $200 \mathrm{~m}$. The $F_{\mathrm{POC}-T h}$ at $200 \mathrm{~m}$ was estimated at A3-2/1, consistent with UVP observations that did not record any $V_{\mathrm{T}}$ increase.

\subsection{Simulations}

\subsubsection{Development of the phytoplankton bloom}

The phytoplankton in the model grew exponentially in the upper part of the water column for the first $8 \mathrm{~d}$ of the simulation, slowing down as light limitation became important (Fig 9a). The specific rate of integrated population growth ( 0 to $150 \mathrm{~m}$ ) was $\sim 0.06 \mathrm{~d}^{-1}$ for this initial period. The peak phytoplankton biomass was $2 \mu \mathrm{g} \mathrm{Chl} \mathrm{\textrm {L } ^ { - 1 }}$ at about $10 \mathrm{~m}$ depth on day 13. The phytoplankton biomass decreased slightly when coagulation became an important removal mechanism by day 20 , with surface phytoplankton biomass of $1.7 \mu \mathrm{g} \mathrm{Chl} \mathrm{L}-1$, a maximum concentration of $1.9 \mu \mathrm{g} \mathrm{Chl} \mathrm{L}^{-1}$ at $15 \mathrm{~m}$, and a minimum concentration of $0.2 \mu \mathrm{g} \mathrm{Chl} \mathrm{L} \mathrm{L}^{-1}$ at $150 \mathrm{~m}$. Surface nitrate concentrations decreased from the initial 30 to $25 \mu \mathrm{M}$ by day 20 (Fig. 9 b).

\subsubsection{Development of the aggregate volume}

Aggregates with $d_{\mathrm{a}}>100 \mu \mathrm{m}$ appeared by day 14 , when the total volume peaked at $1.3 \mathrm{ppm}$ at $40 \mathrm{~m}$ (Fig. 9c). As the phytoplankton biomass increased, the maximum total volume also increased. The depth of the aggregate maximum deepened as the aggregates sank, becoming $17 \mathrm{ppm}$ below $140 \mathrm{~m}$ on day 18. By day 20, the initial rapid coagulation phase ended, with the maximum phytoplankton biomass decreasing 
Table 3. Comparison of the POC fluxes $\left(F_{\mathrm{POC}}\right.$ in $\left.\mathrm{mg} \mathrm{m}^{-2} \mathrm{~d}^{-1}\right)$ derived from particle size distributions from the UVP, particle distributions from gel-filled sediment traps and sediment trap PPS3/3 Technicap Inc, France (Laurenceau et al., 2014) during KEOPS2 and KEOPS1 (Jouandet et al., 2011, Ebersbach and Trull, 2008).

\begin{tabular}{llllll}
\hline & & $\begin{array}{l}\text { Winter } \\
\text { KEOPS2 }\end{array}$ & $\begin{array}{l}\text { Spring } \\
\text { KEOPS2 }\end{array}$ & $\begin{array}{l}\text { Midsummer } \\
\text { KEOPS 1 }\end{array}$ & $\begin{array}{l}\text { End summer } \\
\text { KEOPS1 }\end{array}$ \\
\hline $\begin{array}{l}F_{\mathrm{POC}} \text { at } 200 \mathrm{~m} \\
\left(\mathrm{mg} \mathrm{m}^{-2} \mathrm{~d}^{-1}\right)\end{array}$ & $\begin{array}{l}F=\mathrm{Ad}^{\mathrm{b}} \\
\text { Gel trap } \\
\text { Trap PPS3 }\end{array}$ & 1.75 & $\begin{array}{l}23.11 \\
66\end{array}$ & 869 & 58 \\
\hline $\begin{array}{l}F_{\mathrm{POC}} \text { at } 350 \mathrm{~m} \\
\left(\mathrm{mg} \mathrm{m}^{-2} \mathrm{~d}^{-1}\right)\end{array}$ & $F=\mathrm{Ad}^{\mathrm{b}}$ & 1.04 & 3.50 & 326 & 67 \\
\hline
\end{tabular}
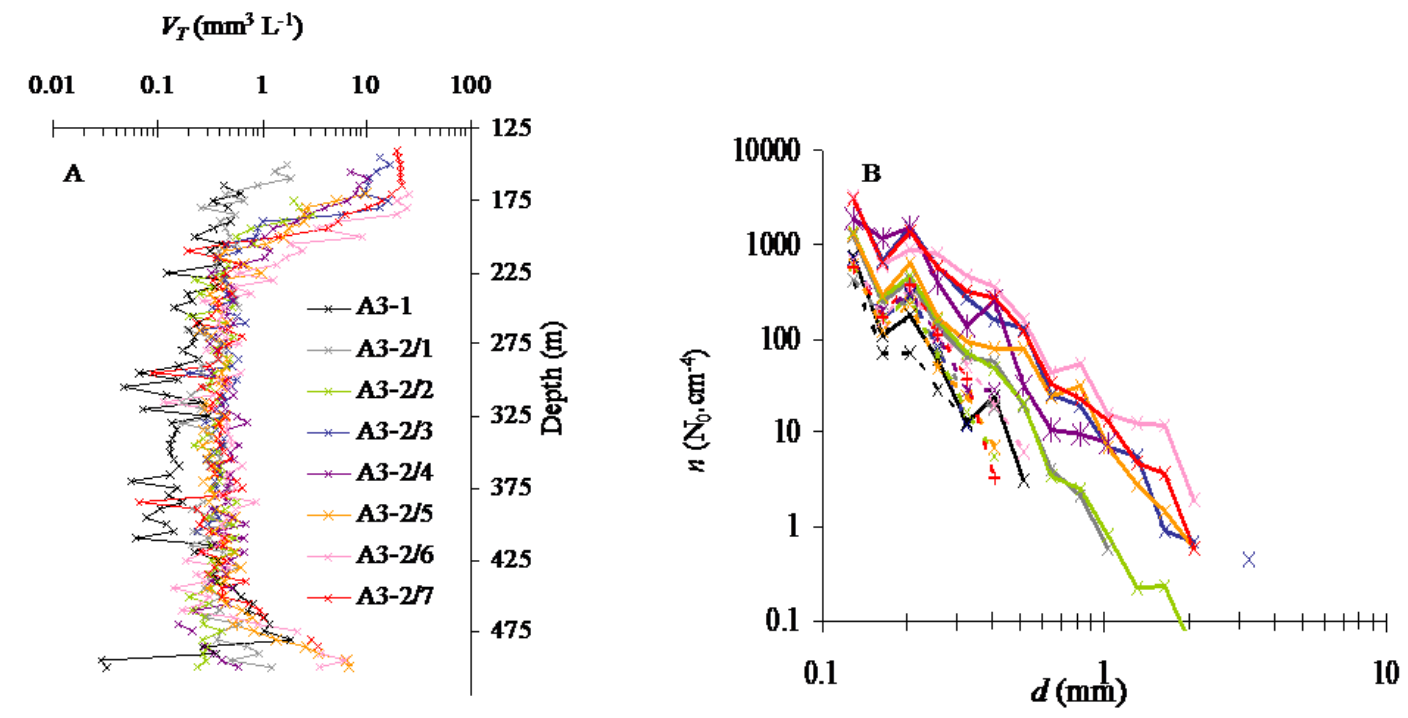

Figure 7. Distribution of $V_{\mathrm{T}}$ below the surface mixed layer (A). Normalized particles size spectra abundance average over the $320-350 \mathrm{~m}$ layer (dotted line) and 100-200 m layer (solid line) (B).

slightly in the upper $50 \mathrm{~m}$ and the aggregates at the base of the mixed layer slowly decreasing. The vertical size distribution at day 20 provides further details on the system (Fig. 10). The $n V d_{\mathrm{a}}$ size distribution shows the distribution of particle volume, with the area under the curve being proportional to the particle volume when displayed with a logarithmic $d_{\mathrm{a}}$ axis, as here (Fig. 10). Most particle volume at the surface is made up the smallest particles, the single phytoplankton cells. At $10 \mathrm{~m}$ depth, aggregates appear with a maximum $n V d_{\mathrm{a}}$ value at $d_{\mathrm{a}}=200 \mu \mathrm{m}$. With increasing depth, the total volume and the diameter of the maximum $n V d_{\mathrm{a}}$ both increase. The $d_{\mathrm{a}}$ at the maximum became $0.9 \mathrm{~mm}$ at about $70 \mathrm{~m}$ depth, remaining constant with increasing depth, even though the total volume continued to increase with depth.

\section{Discussion}

\subsection{Role of coagulation in the rapid changes observed}

There are several striking correspondences between the observations at A3 during KEOPS2 and the one-dimensional coagulation model used here. First, the formation of large aggregates observed over the short timescale $(<2 \mathrm{~d})$ was mimicked by the model. The simulation results highlight the ability of coagulation to change the system state on short timescales that require a frequent sampling regime for them to be observed. The shapes of the $n V d$ spectra at the base of the mixed layer, centered at $0.9 \mathrm{~mm}$ for the model and $1 \mathrm{~mm}$ for the observations, with half widths of $1 \mathrm{~mm}$ for the model and $0.6 \mathrm{~mm}$ for A3-2/5 (Figs. 6 and 10), were very similar. The transition to rapid coagulation took place when relatively little of the initial nitrate had been consumed in the model $(4 \mu \mathrm{M})$, consistent with the $3.6 \mu \mathrm{M}$ decrease observed from A3-1 to A3-2 (Figs. 3 and 9). 


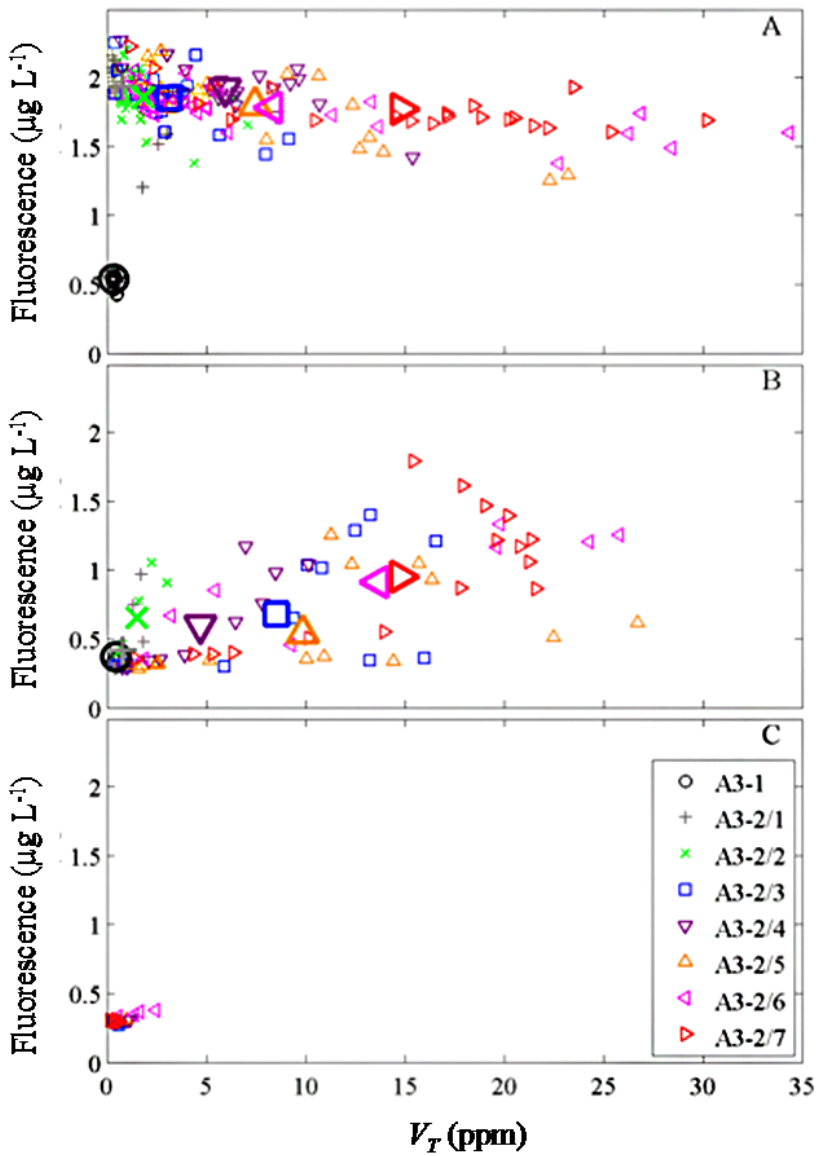

Figure 8. Scatter plots of fluorescence and $V_{\mathrm{T}}$ for the three layers: surface to base of ML (A), base of ML to 200 (B), and $>200 \mathrm{~m}$ (C). Large symbols indicate the means for a profile in the panel depth range.

Coagulation theory has been used to predict the maximum phytoplankton biomass in the ocean (e.g., Jackson and Kiørboe, 2008). Coagulation of phytoplankton cells is a nonlinear process. Rates increase dramatically as phytoplankton biomass increases, eventually removing cells as fast as they divide. The volume concentration at which this occurs is the critical volume concentration (Jackson, 2005):

$V_{\mathrm{cr}}=\pi \mu(8 \alpha \gamma)^{-1}$.

For this calculation, we assumed an average specific growth rate for the population increase rate $\mu=0.1 \mathrm{~d}^{-1}$, in agreement with measurements made by Closset et al. (2014), $\alpha=1$, and $\gamma=1 \mathrm{~s}^{-1}$. Note that the average increase rate is not the same as the peak rate $G_{\max }$. For a POC : volume ratio of $0.17 \mathrm{~g} \mathrm{C} \mathrm{cm}^{-3}$ (Jackson and Kiørboe, 2008) and a carbon to chlorophyll ratio of $50 \mathrm{~g} \mathrm{C}: \mathrm{g} \mathrm{Chl}$, this is equivalent to $1.5 \mu \mathrm{g} \mathrm{Chl} a \mathrm{~L}^{-1}$. This value for $V_{\text {cr }}$ is remarkably close to the maximum concentrations of 2-2.2 $\mu \mathrm{g} \mathrm{Chl} a \mathrm{~L}^{-1}$ observed during the particle formation at A3-2.
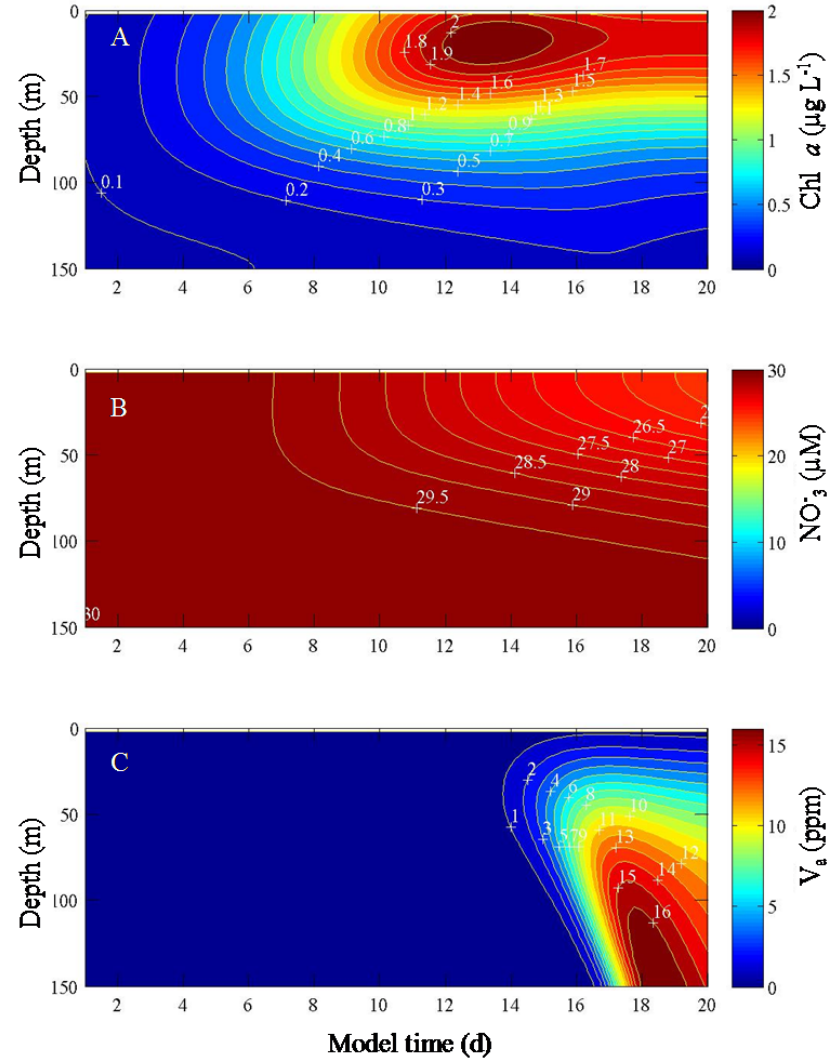

Figure 9. Model results for vertical distribution through time of phytoplankton ( $\left.\mu \mathrm{g} \mathrm{Chl} \mathrm{L}^{-1}\right)(\mathbf{A}$; phytoplankton concentration does not include any algae present in aggregates), nitrate $(\mu \mathrm{M})(\mathbf{B})$, and $V_{\mathrm{Ta}}(\mathrm{ppm})(\mathbf{C})$. Contour interval is $0.1 \mu \mathrm{g} \mathrm{Chl} \mathrm{L}{ }^{-1}(\mathbf{A}), 0.5 \mu \mathrm{M}(\mathbf{B})$, and $1 \mathrm{ppm}(\mathbf{C})$. The calculation assumes that the UVP only measures aggregates larger than $100 \mu \mathrm{m}$.

The rapid production of aggregates at Station A3 observed in this study provides an impressive example of the importance of coagulation in controlling PSD and vertical export of primary production.

The nature of the exported material collected in a freedrifting sediment gel trap at $210 \mathrm{~m}$ supports also the importance of algal coagulation in forming the exported material (Laurenceau et al., 2014). Their analysis shows that the particle flux number and volume were dominated by phytoaggregates over the $0.071-0.6 \mathrm{~mm}$ size range.

\subsection{Limitations of the model}

There are, not unexpectedly, differences between model results and observations. To start, fluorescence profiles are relatively constant through the surface mixed layer in the observations, but have a pronounced shallow subsurface chlorophyll maximum in the model because of the higher light levels near the surface. Increased mixing in the model could smooth the chlorophyll profiles, as well as the distribution of particle volume. Simulations made using a much larger 


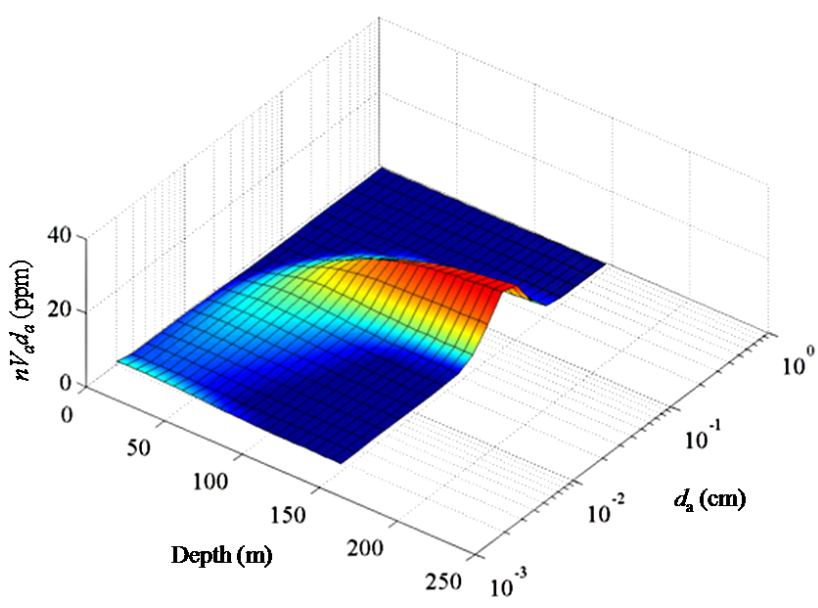

Figure 10. Distribution of apparent particle volume, $n V d_{\mathrm{a}}$, as a function of depth and $d_{\mathrm{a}}$ as calculated by the model at $20 \mathrm{~d}$. Because the value of $d_{\mathrm{a}}$ is plotted on a logarithmic scale, the area under the curve for each depth is proportional to total particle volume $V_{\mathrm{Ta}}$.

mixing coefficient $\left(1000 \mathrm{~m}^{2} \mathrm{~d}^{-1}\right)$ yield a smaller difference in chlorophyll between the surface and $150 \mathrm{~m}$, but there is still a difference of $0.8 \mu \mathrm{g} \mathrm{Chl} \mathrm{L}{ }^{-1}$ over the depth range (results not shown). The vertical mixing rate estimated for the iron fertilization experiment EIFEX, $29 \mathrm{~m}^{2} \mathrm{~d}^{-1}$, was actually smaller than that used in these simulations, namely $100 \mathrm{~m}^{2} \mathrm{~d}^{-1}$ (Smetacek et al., 2012). A previous model of phytoplankton growth in the Kerguelen region discussed large-scale horizontal patterns but unfortunately did not display vertical distribution (Mongin et al., 2008). Whatever the reason for the relatively uniform fluorescence profile, it is not simply a faster diffusive mixing rate. Those differences illustrate the difficulty of building a realistic phytoplankton growth model in the region to drive the coagulation model. The shallower phytoplankton distribution does affect the distribution of aggregates as well.

In a model such as the one used in the present study, there are many parameters and modeled processes that influence the final results. These include parameters such as the fractal dimension, the size of the phytoplankton cells, or processes to describe diatom chain growth, disaggregation rates, and grazing. While the parameters could be tuned systematically to give an improved fit, what is striking is the similarity between observations and the model without such a systematic fitting procedure. One important parameter that was varied during model development to adjust the results was the fractal dimension. Decreasing it decreased the diameter of the peak value of $n V d$. The value that was chosen, $D_{\mathrm{fr}}=2$, was similar to some of the estimates of fractal dimension noted above and did provide the correct $n V d$ distribution when coagulation occurred.

Other processes are known to affect particle concentrations and fluxes, most notably physical process such as advection and biological processes such as zooplankton grazing and fecal pellet production (e.g., Lampitt et al., 1993; Stemmann et al., 2000; Turner et al., 2002). The importance of advection could be inferred from time series measurements of LADCP (Lowered Acoustic Doppler Current Profiler). The results indicated a current below $0.1 \mathrm{~m} \mathrm{~s}^{-1}$, with negligible changes over the survey in the $0-200 \mathrm{~m}$ depth layer (Y. H. P. Park, personal communication, 2014). The abundance and volume of zooplankton larger than $0.7 \mathrm{~mm}$, as well as fecal sticks/pellets and aggregates, were estimated from the identification of organisms in the vignettes recorded by the UVP using the Zooprocess imaging software (see Picheral et al., 2010). The volume of copepods did not increase through the early bloom survey, suggesting that they were not responsible for the observed rapid increase in particles. Ingestion rates were also estimated from zooplankton biomass using the relationship detailed in Carlotti et al. (2008) using the biomass results integrated over the 0 $250 \mathrm{~m}$ layer. The ingestion rate was $1.36 \mathrm{mg} \mathrm{Cd}^{-1}$ during the early bloom cast and lower than during the KEOPS 1 summer cruise. In addition, fecal pellet production should have a diurnal signal (Carlotti et al., 2014), which was not observed in the $V_{\mathrm{T}}$ profiles. Lastly, fast-sinking fecal pellets are much smaller than the aggregates observed here. For example, fecal pellets falling at $100 \mathrm{~m} \mathrm{~d}^{-1}$ are typically $2-$ $5 \times 10^{6} \mu \mathrm{m}^{3}$, equivalent to $d=200 \mu \mathrm{m}$ (Small et al., 1979), compared to the millimeter-sized aggregates dominating at A3. Thus, changes in zooplankton populations can be ruled out as an explanation of the observed $V_{\mathrm{T}}$ increase at this time, although not through the entire season. Modeling the dynamics of the entire season would require integrating zooplankton activity.

\subsection{Comparison with other studies}

\subsubsection{KEOPS1}

The comparison of our results with the size spectra obtained from UVP measurements at Station A3 during the early bloom (KEOPS2) and the late stage of the bloom (KEOPS1) allows us to investigate the seasonal variability of particle production in the $0-200 \mathrm{~m}$ layer and the POC export flux (Fig. 11, Table 3). During summer (KEOPS1), the phytoplankton community was also dominated by Chaetoceros but shifted to Eucampia antarctia by the end of the bloom (Armand et al., 2008). Zooplankton abundance was tenfold higher than during the early bloom and the community was dominated by copepods at copepodite stage (Carlotti et al., 2008). The mixed layer decreased from $150 \mathrm{~m}$ during early bloom to $70 \mathrm{~m}$ during summer. During KEOPS2, $V_{\mathrm{T}}$ increased more than twentyfold from pre-bloom conditions, probably as a result of the higher diatom biomass (L. Armand, personal communication, 2014), and coagulation as described in Sect. 4.1. The value of $V_{\mathrm{T}}$ achieved by the time of the bloom decline in February (KEOPS1) was quite similar to that measured during early bloom for KEOPS2 but the 

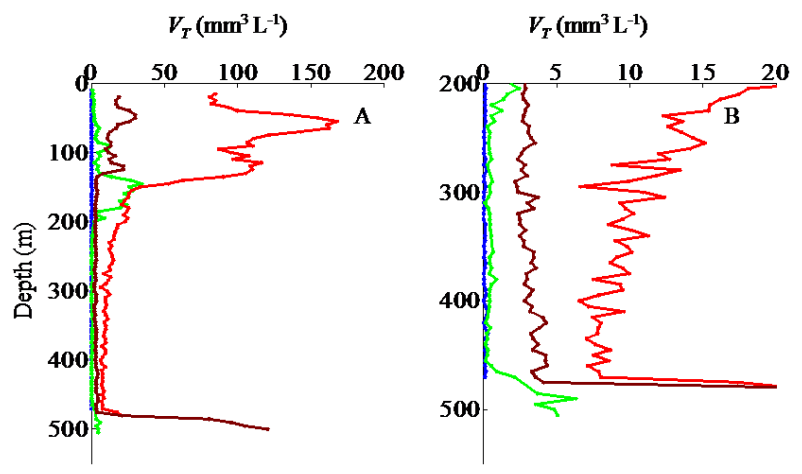

plain the dominance of fecal aggregates in the gel traps during the summer deployments. Combining KEOPS cruises to describe temporal scales of particle production and export (transient versus seasonal) is useful as a first step, but our limited observations highlight the need for high-frequency data collection over long periods.

\subsubsection{Potential impact of coagulation after iron fertilization}
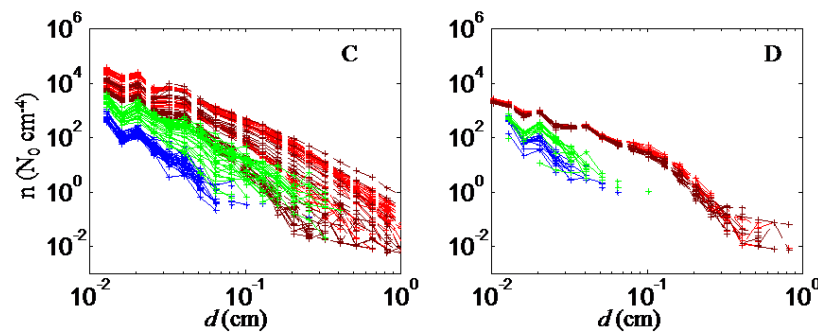

Figure 11. (A, B) Comparison of the total volume profiles measured during KEOPS2 in October (A3-1, blue), November (A3-2/7, green), and during KEOPS1 in January (red) and February (brown). The depth scale for (B) is enlarged and covers only $200-500 \mathrm{~m}$. (C, D) Comparison of the normalized size spectra in the $0-200 \mathrm{~m}$ (C) and 200-400 $\mathrm{m}$ layer (D). The colors indicate the same profiles as in $(\mathbf{A}, \mathbf{B})$.

vertical structure was different, with two subsurface maxima during KEOPS1, the first one present at the base of the ML $(70 \mathrm{~m})$. The larger $V_{\mathrm{T}}$ measured in January was associated with an increase in the fraction of large particles (Fig. 11c).

Below $200 \mathrm{~m}$ depth, $V_{\mathrm{T}}$ was still 10 times higher during the peak bloom as compared to early bloom. This resulted in forty- (at $200 \mathrm{~m}$ ) and tenfold (at $400 \mathrm{~m}$ ) higher carbon export fluxes during the peak bloom than the early bloom (Table 3 ). During the decline of the bloom, $V_{\mathrm{T}}$ and POC flux were still higher than during early bloom. This is consistent with the general scheme of low-production-high-export at the end of the bloom put forward by Wassmann (1998). Our results provide insights into particle production and size distributions at different stages of the seasonal bloom. The early bloom occurs before zooplankton grazing dominates. This leads to a large increase in diatom abundance resulting in rapid aggregate formation and export from the surface ML. Later in the season, export becomes controlled by zooplankton grazing and fecal pellet production, as found through the gel trap analysis (Ebersbach and Trull, 2008). Despite the importance of zooplankton grazing in the late season, the presence of $V_{\mathrm{T}}$ maxima at the base of the ML indicates that coagulation still occurred during summer. An increase of aggregate formation through coagulation as a result of high cell numbers in the ML and their disappearance due to grazing between the base of the mixed layer and $200 \mathrm{~m}$ traps could also ex-

Our results can be compared to those from other iron fertilization experiments to understand the relative roles of coagulation and zooplankton grazing on particle export during different parts of the bloom cycle. However, it must be remembered that fertilization experiments differ in important aspects, including location, physical and chemical regimes, and observational techniques applied to determine stocks and fluxes. In addition, conclusions about carbon export from the surface often depend on sediment traps that are usually located well below the euphotic zone or surface ML, sampling events that have been filtered by intervening processes and offset by transit times. With this in mind, we compare our results to those from other iron fertilization studies by classifying them into those with phytodetritus export driven by diatoms on the one hand and the rest, including those with a zooplankton-mediated export, on the other hand.

The artificial iron fertilization experiment SOIREE (February 1999) found an increase in phytoplankton biomass (Chl $a=2 \mathrm{mg} \mathrm{m}^{-3}$ ) as a result of the iron addition, but no rapid removal of phytoplankton production. The export flux was low and driven by phyto-detrital aggregates (Waite and Nodder, 2001). Jackson et al. (2005) argued that the final abundance of phytoplankton cells was too low for rapid coagulation and sinking. There was a change in diatom settling rate associated with a change in iron status. The persistence of the bloom after iron was depleted implies that zooplankton grazing was not removing the particulate material.

The EIFEX (February-March 2004) environment was remarkably similar to that of KEOPS2 (Smetacek et al., 2012). The mixed layer was slightly shallower during EIFEX $(100 \mathrm{~m})$ than during KEOPS2 $(150 \mathrm{~m})$, but still relatively deep; the phytoplankton accumulation rates were also similar $\left(0.03\right.$ to $\left.0.11 \mathrm{~d}^{-1}\right)$. Iron fertilization stimulated a large diatom bloom that reached concentrations of about $2 \mathrm{mg} \mathrm{Chl} a \mathrm{~m}^{-3}$ 4 weeks after the fertilization started. There was little effect on vertical export during the first 4 weeks, but export then increased rapidly to $110-140 \mathrm{mmol} \mathrm{C} \mathrm{m}^{-2} \mathrm{~d}^{-1}$. This change was associated with mass mortality of several diatom species that formed rapidly sinking, mucilaginous aggregates of entangled cells and chains (Smetacek et al., 2012). This pattern of rapid formation of algal cells late in the bloom is similar to what we observed.

CROZEX investigated the impact of high biomass (Chl $a=2 \mathrm{mg} \mathrm{m}^{-3}$ ) associated with the bloom decline in carbon export during 2 legs (November 2004 and January 
2005) (Venables et al., 2007). Carbon export fluxes estimated from a sediment trap in the highly productive, naturally ironfertilized region of the subantarctic waters were two to three times larger than the carbon fluxes from adjacent HNLC waters (Pollard et al., 2009). Vertical flux was dominated by a diverse range of diatoms, which suggests an important role for direct export, such as by coagulation.

In contrast, the particulate flux project in a region of elevated biomass ( $\mathrm{Chl} a=1.9 \mathrm{mg} \mathrm{m}^{-3}$ ) in the Subantarctic Zone east of Tasmania fueled by enhanced iron was dominated by fecal aggregates (Ebersbach et al., 2011).

The LOHAFEX (loha is the Hindi word for iron) iron fertilization experiment was one of the few to use a particle measuring system for the water column, also the UVP (Martin et al., 2013). A cyclonic eddy low in silica on the Antarctic Polar Frontal Zone was fertilized with iron. In response, phytoplankton biomass almost doubled to 1$1.5 \mathrm{mg} \mathrm{Chl} a \mathrm{~m}^{-3}$, but $90 \%$ of it was in flagellates of less than $10 \mu \mathrm{m}$ instead of diatoms. There was no observable change in concentrations of particles larger than $100 \mu \mathrm{m}$ or in vertical particle flux. There were several reasons proposed for the low export, including the lack of diatoms in the lowsilicate water and intense particle consumption, particularly at the base of the mixed layer $(66 \mathrm{~m})$.

\section{Conclusions}

It is clear that particle flux in the ocean is the result of many interacting processes, and none of these has been identified as dominant across systems. In the present study, we were able to observe rapid aggregate formation and sedimentation of high concentrations of diatoms from the euphotic zone. Our observations are consistent with results from a onedimensional model that includes only phytoplankton growth and coagulation. Our results demonstrate the utility of coagulation theory in understanding vertical flux and its importance in initiating the formation of large particles in the mixed layer and their subsequent transfer to depth during a bloom. Nevertheless, efforts are still required to measure large aggregates distribution at a high frequency to fill the temporal window between these short time events taking place during the early bloom and the possibly slower dynamics of summer. In addition, more effort is required to understand vertical variations better at a fine scale for all times and particularly to estimate the transformative roles of microbes and zooplankton in decreasing the total particle volume exported from the euphotic zone.

The Supplement related to this article is available online at doi:10.5194/bg-11-4393-2014-supplement.
Acknowledgements. Thanks to the Kerguelen Ocean and Plateau Compared Study (KEOPS2) shipboard science team and the officers and crew of R/V Marion Dufresne for their efforts. Christine Klaas provided helpful input on biological conditions. We acknowledge the constructive comments by E. Laurenceau. This research was supported by the French Agency of National Research grant (\# ANR-10-BLAN-0614). G. A. Jackson was supported by US National Science Foundation (NSF) grant OCE09-27863. L. Stemmann was supported by the chair VISION from CNRS/UPMC.

Edited by: G. Herndl

\section{References}

Alldredge, A. L. and Gotschalk, C.: In situ settling behavior of marine snow, Limnol. Oceanogr., 33, 339-351, 1988.

Armand, L. K., Cornet Barthaux, V., Mosseri, J., and Quéguiner, B.: Late summer diatom biomass and community structure on and around the naturally iron-fertilized Kerguelen Plateau in the Southern Ocean, Deep-Sea Res. II, 55, 653-676, 2008.

Assmy, P., Henjes, J., Klaas, C., and Smetacek, V.: Mechanism determining species dominance in a phytoplankton bloom induced by the iron fertilization experiment EisenEx in the Southern Ocean, Deep-Sea Res. Pt. I, 54, 340-362, 2007.

Blain, S., Quéguiner, B., Armand, L., Belviso, S., Bombled, B., Bopp, L.,Bowie, A., Brunet, C., Brussaard, C., Carlotti, F., Christaki, U., Corbière, A., Durand, I., Ebersbach, F., Fuda, J.-L., Garcia, N., Gerringa, L., Griffiths, B., Guigue, C., Guillerm, C., Jacquet, S., Jeandel, C., Laan, P., Lefèvre, D., Lomonaco, C., Malits, A., Mosseri, J., Obernosterer, I., Park, Y.-H., Picheral, M., Pondaven, P., Remeny, T., Sandroni, V., Sarthou, G., Savoye, N., Scouarnec, L., Souhaut, M., Thuiller, D., Timmermans, K., Trull, T., Uitz, J., van-Beek, P., Veldhuis, M., Vincent, D., Vio1lier, E., Vong, L., and Wagener, T.: Effect of natural iron fertilization on carbon sequestration in the Southern Ocean, Nature, 446, 1070-1074, 2007.

Boyd, P. W., Watson, A. J., Law, C. S., Abraham, E. R., Trull, T., Murdoch, R., Bakker, D. C. E., Bowie, A. R., Buesseler, K. O., Chang, H., Charette, M., Croot, P., Downing, K., Frew, R., Gall, M., Hadfield, M., Hall, J., Harvey, M., Jameson, G., LaRoche, J., Liddicoat, M., Ling, R., Maldonado, M. T., McKay, R. M., Nodder, S., Pickmere, S., Pridmore, R., Rintoul, S., Safi, K., Sutton, P., Strzepek, R., Tanneberger, K., Turner, S., Waite, A., and Zeldis, J.: A mesoscale phytoplankton bloom in the polar Southern Ocean stimulated by iron fertilization, Nature, 407, 695-702, 2000.

Boyd, P. W., Law, C. S., Wong, C. S., Nojiri, Y., Tsuda, A., Levasseur, M., Takeda, S., Rivkin, R., Harrison, P. J., Strzepek, R., Gower, J., McKay, R. M., Abraham, E., Arychuk, M., BarwellClarke, J., Crawford, W., Crawford, D., Hale, M., Harada, K., Johnson, K., Kiyosawa, H., Kudo, I., Marchetti, A., Miller, W., Needoba, J., Nishioka, J., Ogawa, H., Page, J., Robert, M., Saito, H., Sastri, A., Sherry, N., Soutar, T., Sutherland, N., Taira, Y., Whitney, F., Wong, S. K. E., and Yoshimura, T.: The decline and fate of an iron-induced subarctic phytoplankton bloom, Nature, 428, 549-553, 2004. 
Buesseler, K. O., Andrews, J. E., Pike, S. M., and Charette, M. A.: The effects of iron fertilization on carbon sequestration in the Southern Ocean, Science, 304, 414-417, 2004.

Buesseler, K. O., Andrews, J. E., Pike, S. M., and Charrette, M. A.: Particle export during the Southern Ocean Iron Experiment (SOFeX), Limnol. Oceanogr., 50, 311-327, 2005.

Burd, A. B. and Jackson, G. A.: Particle aggregation, Annu. Rev. Mar. Sci., 1, 65-90, 2009.

Carlotti, F., Thibault-Botha, D., Nowaczyk, A., and Lefèvre, D.: Zooplankton community structure, biomass, and role in carbon fluxes during the second half of a phytoplankton bloom in the eastern sector of the Kerguelen Shelf (January-February 2005), Deep-Sea Res. Pt. II, 55, 720-733, 2008.

Carlotti, F., Harmelin, M., Nowaczik, A., Jouandet, M.-P., Lefèvre, D.: Mesozooplankton structure and functioning during the onset of the Kerguelen Bloom during KEOPS2 survey, Biogeosciences, 11, in preparation, 2014.

Chever, F., Sarthou, G., Bucciarelli, E., Blain, S., and Bowie, A. R.: An iron budget during the natural iron fertilisation experiment KEOPS (Kerguelen Islands, Southern Ocean), Biogeosciences, 7, 455-468, doi:10.5194/bg-7-455-2010, 2010.

Closset, I., Lasbleiz, M., Leblanc, K., Quéguiner, B., Cavagna, AJ., Elskens, M., Navez, J., and Cardinal, D.: Seasonal evolution of net and regenerated silica production around a natural $\mathrm{Fe}$ fertilized area in the Southern Ocean estimated from $\mathrm{Si}$ isotopic approaches, Biogeosciences, 11, in review, 2014.

De Baar, H. J. W., Boyd, P. W., Coale, K. H., Landry, M. R., Tsuda, A., Assmy, P., Bakker, D. C. E., Bozec, Y., Barber, R. T., Brzezinski, M. A., Buesseler, K. O., Boye, M., Croot, P. L., Gervais, F., Gorbunov, M. Y., Harrison, P. J., Hiscock,W. T., Laan, P., Lancelot, C., Law, C. S., Levasseur, M., Maretti, A., Millero, F. J., Nishioka, J., Nojiri, Y., van Oijen, T., Riebesell, U., Rijkenberg, M. J. A., Saito, H., Takeda, S., Timmermans, K. R., Veldhuis, M. J. W., Waite, A. M., and Wong, C.H.: Synthesis of iron fertilization experiments: from the iron age in the age of enlightenment, J. Geophys. Res., 110, C09S16, doi:10.1029/2004JC002601, 2005.

Ebersbach, F. and Trull, T. W.: Sinking particle properties from polyacrylamide gels during KEOPS: Controls on carbon export in an area of persistent natural iron inputs in the Southern Ocean, Limnol. Oceanogr., 53, 212-224, doi:10.4319/lo.2008.53.1.0212, 2008.

Ebersbach, F., Trull, T. W., Davies, D., Moy, C., Bray, S. G., and Bloomfield, C.: Controls on mesopelagic particle fluxes in the Sub-Antarctic and Polar Frontal Zones in the Southern Ocean south of Australia in summer - perspectives from free-drifting sediment traps, Deep-Sea Res. Pt. II, 58, 2260-2276, 2011.

Evans, G. T. and Parslow, J. S.: A model of annual plankton cycles, Biol. Oceanogr., 3, 327-347, 1985.

Fasham, M. J. R., Ducklow, H. W., and McKelvie, S. M.: A nitrogen-based model of plankton dynamics in the ocean mixed layer, J. Mar. Res., 48, 591-639, 1990.

Fasham, M. J. R., Flynn, K. J., Pondaven, P., Anderson, T. R., and Boyd, P. W.: Development of a robust ecosystem model to predict the role for iron in biogeochemical cycles: a comparison of results for iron-replete and iron-limited areas, and the SOIREE iron-enrichment experiment, Deep-Sea Res., 53, 333-366, 2006.

Gervais, F., Riebesell, U., and Gorbunov, M. Y.: Changes in primary productivity and chlorophyll $a$ in response to iron fertilization in the southern Polar Frontal Zone, Limnol. Oceanogr., 47, 13241335, 2002.

Guidi, L., Jackson, G., A., Stemmann, L., Miquet, J. C., Picheral, M., and Gorsky, G.: Relationship between particle size distribution and flux in the mesopelagic zone, Deep-Sea Res. Pt. I, 55, 1364-1374, doi:10.1016/j.dsr.2008.05.014, 2008.

Hoffmann, L. J., Peeken, I., Lochte, K., Assmy, P., and Veldhuis, M.: Different reactions of Southern Ocean phytoplankton size classes to iron fertilization, Limnol. Oceanogr., 51, 1217-1229, 2006.

Jackson, G. A.: Comparing observed changes in particle size spectra with those predicted using coagulation theory, Deep-Sea Res. Pt. II, 42, 159-184, 1995.

Jackson, G. A.: Coagulation theory and models of oceanic plankton, in: Flocculation in Natural and Engineered Environmental Systems, edited by: Droppo, I., Leppard, G., Liss, S., and Milligan, T., CRC Press, Boca Raton, FL, 271-292, 2005.

Jackson, G. A. and Kiørboe, T.: Maximum phytoplankton concentrations in the sea, Limnol. Oceanogr., 53, 395-399, 2008.

Jackson, G. A., Waite, A. M., and Boyd, P. W.: Role of algal aggregation in vertical carbon export during SOIREE and in other low biomass environments, Geophys. Res. Lett., 32, L13607, doi:10.1029/2005GL023180, 2005.

Jouandet, M. P., Blain, S., Metzl, N., Brunet, C., Trull, T. W., and Obernosterer, I.: A seasonal carbon budget for a naturally iron-fertilized bloom over the Kerguelen Plateau in the Southern Ocean, Deep-Sea Res. Pt. II, 55, 856-867, doi:10.1016/j.dsr2.2007.12.037, 2008.

Jouandet, M. P., Trull, T. W., Guidi, L., Picheral, M., Ebersbach; F., Stemmann, L., and Blain, S.: Optical imaging of mesopelagic particles indicates deep carbon flux beneath a natural ironfertilized bloom in the Southern Ocean, Limnol. Oceanogr., 5, 1130 1140, 2011.

Lampitt, R. S., Wishner, K. F., Turley, C. M., and Angel, M. V.: Marine snow studies in the Northeast Atlantic Ocean: distribution, composition and role as a food source for migrating plankton, Mar. Biol., 116, 689-702, 1993.

Lasbleiz, M., Leblanc, K., Blain, S., Ras, J., Cornet-Barthaux, V., Helias Nunige, S., and Queguiner, B.: Pigments, elemental composition $(\mathrm{C}, \mathrm{N}, \mathrm{P}, \mathrm{Si})$ and stoichiometry of particulate matter, in the naturally iron fertilized region of Kerguelen in the Southern Ocean, 2014.

Laurenceau, E., Trull, T. W., Davies, D. M., Bray, S. G., Doran, J., Planchon, F., Carlotti, F., Jouandet, M.-P., Cavagna, A.-J., Waite, A. M., and Blain, S.: Importance of ecosystem structure to carbon export: insights from free-drifting trap deployments in naturally iron-fertilised waters near the Kerguelen plateau, Biogeosciences, 11, in preparation, 2014.

Martin, P., Rutgers van der Loeff, M., Cassar, N., Vandromme, P., d'Ovidio, F., Stemmann, L.,Rengarajan, R., Soares, M., González, H. E., Ebersbach, F., Lampitt, R. S., Sanders, R., Barnett, B. A., Smetacek, V., and Naqvi, S. W. A.: Iron fertilization enhanced net community production but not downward particle flux during the Southern Ocean iron fertilization experiment LOHAFEX, Global Biogeochem. Cy., 27, 871-881, doi:10.1002/gbc.20077, 2013.

Mongin, M., Moliant, M., and Trull, T. W.: Seasonality and scale of the Kerguelen plateau phytoplankton bloom: A remote sensing and modeling analysis of the influence of natural iron fertiliza- 
tion in the Southern Ocean, Deep-Sea Res. Pt. II, 55, 880-892, 2008.

Moore, J. K. and Abbott, M. R.: Surface chlorophyll concentrations in relation to the Antarctic Polar Front: seasonal and spatial patterns from satellite observations, J. Mar. Syst., 37,69-86, 2002.

Park, Y. H., Fuda, J. L., Durand, I., and Naveira Garabato, A.C: Internal tides and vertical mixing over the Kerguelen Plateau, Deep-Sea Res. Pt. II, 55, 583-593, 2008a.

Park, Y., Roquet, F., Fuda, J. L., and Durand, I.: Large scale circulation over and around the Kerguelen Plateau, Deep-Sea Res. Pt. II, 55, 566-581, doi:10.1016/j.dsr2.2007.12.030, 2008b.

Picheral, M., Guidi, L., Stemmann, L., Karl, D. M., Iddaoud, G., and Gorsky G: The Underwater Vision Profiler 5: An advanced instrument for high spatial resolution studies of particle size spectra and zooplankton, Limnol. Oceanogr.-Methods, 8, 462-473, doi:10.4319/lom.2010.8.462, 2010.

Planchon, F., Ballas, D., Cavagna, A.-J., van der Merwe, P., Bowie, A. W., Trull, T. W., Laurenceau , E., Davis, D. M., and Dehairs, F.: Carbon export in the naturally iron-fertilized Kerguelen area of the Southern Ocean using ${ }^{234}$ Th-based approach, Biogeosciences, 11, in preparation, 2014.

Pollard, R. T., Venables, H. J., Read, J. F., and Allen, J. T.: Large scale circulation around the Crozet Plateau controls an annual phytoplankton bloom in the Crozet Basin, Deep-Sea Res. Pt. II, 54, 1905-1914, doi:10.1016/j.dsr2.2007.06.012, 2007.

Pollard, R. T., Salter, I., Sanders, R. J., Lucas, M. I., Moore, C. M., Mills, R. A., Statham, P. J., Allen, J. T., Baker, Al. R., Bakker, D. C. E., Charette, M. A., Fielding, S., Fones, G. R., French, M., Hickman, A. E., Holland, R. J., Hughes, J. A., Jickells, T. D., Lampitt, R. S., Morris, I., Nédélec, F. H., Nielsdóttir, M., Planquette, H., Popova, E. E., Poulton, A. J., Read, J. F., Seeyave, S., Smith, T., Stinchcombe, M., Taylor, S., Thomalla, S., Venables, H. J., Williamson, R., and Zubkov, M. V.: Southern Ocean deep-water carbon export enhanced by natural iron fertilization, Nature, 457, 577-580, doi:10.1038/nature07716, 2009.

Salter, I., Lampitt, R. S., Sanders, S., Poulton, A. J., Kemp, A. E. S., Boorman, B., Saw, K., and Pearce, R.: Estimating carbon, silica and diatom export from a naturally fertilized phytoplankton bloom in the Southern Ocean using PELAGRA: a novel drifting sediment trap, Deep-Sea Res. Pt. II, 2233-2259, doi:10.1016/j.dsr2.2007.07.008, 2007.

Savoye, N., Trull, T. W., Jacquet, S., Navez, J., and Dehairs, F.: ${ }^{234} \mathrm{Th}$ based export fluxes during a natural iron fertilization experiment in the southern ocean (KEOPS), Deep-Sea Res. Pt. II, 55, 841-855, doi:10.1016/j.dsr2.2007.12.036, 2008.
Small, L. F., Fowler, S. W., and Ümlü, M. U.: Sinking rates of natural copepod fecal pellets, Mar. Biol., 51, 233-241, 1979.

Smetacek, V., Klaas, C., Strass, V. H., Assmy, P., Montresor, M., Cisewski, B., Savoye, N., Webb, A., d'Ovidio, F., Arrieta, J. M., Bathmann, U., Bellerby, R., Berg, G. M., Croot, P., Gonzalez, S., Henjes, J., Herndl, G. J., Hoffmann, L. J., Leach, H., Losch, M., Mills, M. M., Neill, C., Peeken, I., Röttgers, R., Sachs, O., Sauter, E., Schmidt, M. M., Jill Schwarz, J., Terbrüggen, U., and Wolf-Gladrow, D.: Deep carbon export from a Southern Ocean iron-fertilized diatom bloom, Nature, 287, 313-319, 2012.

Stemmann, L., Picheral, M., and Gorsky, G.: Diel variation in the vertical distribution of particulate matter $(>0.15 \mathrm{~mm})$ in the NW Mediterranean Sea investigated with the Underwater Video Profiler, Deep-Sea Res. Pt. I, 47, 505-31, 2000.

Timmermans, K. R., van der Wagt, B., and de Baar, H. J. W.: Growth rates, half-saturation constants, and silicate, nitrate, and phosphate depletion in relation to iron availability of four large, openocean diatoms from the Southern Ocean, Limnol. Oceanogr., 49, 2141-2151, 2004

Tréguer, P. and LeCorre, P.: Manuel d'analyse des sels nutritifs dans l'eau de mer (Utilisation de l'autoAnalyseur II), 2nd edn., Laboratoire d'Océanographie chimique, Univ. de Bretagne Occidentale, 1975.

Turner, J. T.: Zooplankton fecal pellets, marine snow and sinking phytoplankton blooms, Aquat. Microb. Ecol., 27, 57-102, 2002.

Tyrrell, T., Merico, A., Waniek, J. J., Wong, C. S., Metzl, N., and Whitney, F.: Effect of seafloor depth on phytoplankton blooms in high-nitrate, low-chlorophyll (HNLC) regions, J. Geophys. Res., 110, G02007, doi:10.1029/2005JG000041, 2005.

Uitz, J., Claustre, H., Morel, A., and Hooker, S. B.: Vertical distribution of phytoplankton communities in open ocean: an assessment based on surface chlorophyll, J. Geophys. Res.-Oceans, 111, C08105, doi:10.1029/2005JC003207, 2006.

Venables, H. J., Pollard, R. T., and Popova, E. K.: Physical conditions controlling the development of a regular phytoplankton bloom north of the Crozet Plateau, Southern Ocean, DeepSea Res. Pt. II, 54, 1949-1965, doi:10.1016/j.dsr2.2007.06.014, 2007.

Waite, A. and Nodder, S. D.: The effect of in situ iron addition on the sinking rates and export flux of Southern Ocean diatoms, DeepSea Res. Pt. II, 48, 2635-2654, 2001.

Wassmann, P.: Retention vs. export food chains: processes controlling sinking loss from marine pelagic systems, Hydrobiologia, 363, 29-57, 1998 